\title{
PROFIL PASIEN STROKE ISKEMIK AKUT DENGAN TERAPI RECOMBINANT TISSUE PLASMINOGEN ACTIVATOR DI RSUP DR. KARIADI SEMARANG
}

\author{
PROFILE OF ACUTE ISCHEMIC STROKE PATIENTS WITH RECOMBINANT TISSUE \\ PLASMINOGEN ACTIVATOR THERAPY IN DR. KARIADI HOSPITAL SEMARANG
}

\author{
Retnaningsih, * Theodorus Kevin Hendartono*
}

\section{ABSTRACT}

Introduction: The use of recombinant tissue plasminogen activator (rtPA) is recommended within 4.5 hours from onset, with door to needle (DTN) time $\leq 60$ minutes, so that it will decrease morbidity and mortality rates.

Aims: To evaluate the evaluate the profile of acute ischemic stroke patients with rtPA therapy in Dr. Kariadi Hospital Semarang.

Methods: This was a descriptive study by looking at medical records of patients with acute ischemic stroke with onset less than 4.5 hours performed rtPA therapy in Dr. Kariadi Hospital Semarang during Januari 2017 until May 2018.

Results: There were 36 patients, 19 (52.8\%) male, 17 (47.2\%) female. Age range from 36 to 74 years with stroke onset 15-180 minutes. There were lacuner ischemia in 29 patients (80.6\%) and teritorial ischemia in 7 patients (19.4\%). The mean DTN time $67.22 \pm 12.29$ with DTN time for rtPA $>60$ minutes was performed in 23 (63.9\%) patients and

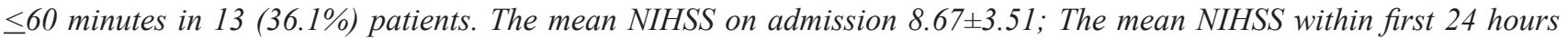

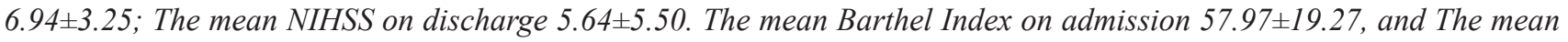
Barthel Index on discharge $73.33 \pm 26.25$.

Discussion: There was an improvement of NIHSS and Barthel Index in acute ischemic stroke patients with rtPA therapy. The mean DTN time still $>60$ minutes, so that service system improvements are needed in order to improve clinical outcomes of acute ischemic stroke patients with rtPA therapy (DTN time $\leq 60$ minutes). $(D T N)$

Keywords: Barthel Index, NIHSS, recombinant tissue plasminogen activator (rtPA), ischemic stroke, door to needle

\section{ABSTRAK}

Pendahuluan: Pemberian recombinant tissue plasminogen activator (rtPA) direkomendasikan dalam waktu sampai 4,5 jam dengan waktu door to needle (DTN) $\leq 60$ menit agar dapat menurunkan tingkat morbiditas dan mortalitas pada stroke iskemik akut.

Tujuan: Untuk mengetahui profil pasien stroke iskemik akut dengan terapi rtPA di RSUP Dr. Kariadi Semarang.

Metode: Penelitian deskriptif dengan melihat rekam medis pasien-pasien stroke iskemik akut periode Januari 2017 hingga Mei 2018 dengan onset kurang dari 4,5 jam yang mendapatkan terapi rtPA di RSUP Dr. Kariadi Semarang.

Hasil: Dari 36 subjek, didapatkan proporsi laki-laki lebih banyak dari pada perempuan (52,8\% vs 47,2\%) dan rerata usia 58 58,63 tahun. Rerata waktu awitan adalah $92,5 \pm 42,79$ menit dengan tipe iskemik lakuner $(80,6 \%)$ dan rerata waktu DTN $67,22 \pm 12,29$ menit. Rerata NIHSS 24 jam pertama adalah $6,94 \pm 3,25$ yang menurun menjadi $5,64 \pm 5,50$ saat keluar RS. Rerata Indeks Barthel subjek saat masuk RS adalah 57,91 $\pm 19,27$ yang meningkat saat keluar menjadi 73,33 $\pm 26,25$.

Diskusi: Terdapat perbaikan nilai NIHSS dan Indeks Barthel pada subjek stroke iskemik akut yang mendapatkan terapi rtPA. Rerata waktu DTN adalah $>60$ menit, menunjukkan perlunya perbaikan sistem pelayanan untuk meningkatkan luaran klinis pasien stroke iskemik akut dengan DTN $\leq 60$ menit.

Kata kunci: Door to needle, Indeks Barthel, NIHSS, recombinant tissue plasminogen activator, stroke iskemik

*Bagian/KSM Neurologi FK Universitas Diponegoro/RSUP Dr. Kariadi, Semarang. Korespondensi: retnaku_icu@yahoo.com.

\section{PENDAHULUAN}

Stroke menjadi penyebab utama kematian dan kecacatan di seluruh dunia, terutama di negara berkembang. Kejadian stroke iskemik lebih sering dibandingkan dengan stroke perdarahan, sekitar 80-85\% dari seluruh kejadian stroke keseluruhan. Patofisiologi stroke iskemik melibatkan respons imunologi yang kompleks mulai dari proses trombosis atau emboli yang menyebabkan kematian sel-sel neuron dalam parenkim otak yang disebut sebagai

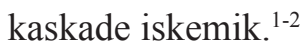

Terapi utama stroke pada fase akut adalah dengan pemberian terapi trombolisis menggunakan rtPA (recombinant-tissue plasminogen activator) 
secara intravena maupun intraarterial kurang dari 3 jam setelah awitan. Dosis yang dianjurkan pada pasien di Asia adalah dosis rendah $0,6 \mathrm{mg} / \mathrm{kgBB}$ (maksimum 60mg), berupa 10\% dosis total diberikan sebagai bolus inisial, dan sisanya dalam infus selama 60 menit. Terapi ini harus diberikan dalam rentang waktu 3-4,5 jam sesuai pedoman American Heart Association/American Stroke Association (AHA/ ASA) class I, level of evidence A. Diharapkan terjadi penghancuran trombus dan reperfusi jaringan otak dan perubahan ireversibel pada otak yang terkena, terutama daerah penumbra sehingga terjadi perbaikan luaran klinis pasien. ${ }^{3-6}$

RSUP Dr. Kariadi Semarang sebagai rumah sakit rujukan di Jawa Tengah telah melaksanakan tata laksana pemberian terapi trombolisis intravena dengan hasil yang memuaskan. Protokol pelayanan stroke iskemik akut dilakukan pada pasien awitan kurang dari 4,5 jam menggunakan alteplase dengan dosis total $0,6 \mathrm{mg} / \mathrm{kgBB}$.

\section{TUJUAN}

Mengetahui profil pasien stroke iskemik akut yang mendapat terapi rtPA di RSUP Dr. Kariadi, Semarang.

\section{METODE}

Penelitian ini adalah penelitian deskriptif berdasarkan data rekam medis pasien stroke iskemik akut yang dilakukan pemberian rtPA dalam kurun waktu 4,5 jam pascastroke di RSUP Dr. Kariadi Semarang pada bulan Januari 2017 hingga Mei 2018.

Subjek dilakukan pencatatan data demografis, pemeriksaan fisik, onset stroke, kadar gula darah sewaktu (GDS), jenis stroke iskemik, lokasi iskemik, waktu door to needle (DTN), lama rawat (length of stay/LOS), skor National Institutes of Health Stroke Scale (NIHSS) saat masuk, 24 jam pertama, dan saat keluar dari RS, serta Indeks Barthel saat keluar dari RS. Penelitian ini telah memperoleh Surat Keterangan Etik dari Komite Etik Penelitian Kesehatan Fakultas Kedokteran Universitas Diponegoro, Semarang.

Jenis dan lokasi iskemik berdasarkan CT scan saat datang awal. Waktu DTN ditentukan sejak pasien memasuki ruang IGD hingga bolus rtPA mulai diberikan kepada pasien. LOS ditentukan dari hari pertama pasien mulai datang ke IGD hingga hari terakhir pasien mendapatkan perawatan di bangsal. NIHSS dan Indeks Barthel saat keluar dari RS dinilai saat subjek dinyatakan boleh pulang dari perawatan. Lembar penilaian NIHSS yang digunakan adalah NIHSS yang telah disesuaikan ke dalam Bahasa Indonesia.

\section{HASIL}

Didapatkan 36 subjek (Tabel 1) dengan proporsi laki-laki dan perempuan yang hampir sama (53\% dan $47 \%$ ) serta rerata usia $58 \pm 8,63$ tahun. Rerata waktu awitan kedatangan subjek 92,5 $\pm 42,79$ menit, rerata GDS saat awal masuk $167,97 \pm 89,51 \mathrm{mg} / \mathrm{dL}$, rerata tekanan darah sistolik $150,97 \pm 22,96 \mathrm{mmHg}$, dan rerata tekanan darah diastolik $86,86 \pm 13,30 \mathrm{mmHg}$. Hasil CT scan kepala didapatkan mayoritas tipe iskemik lakuner $(80,6 \%)$ dan lokasi di hemisfer dominan $(52,8 \%)$.

Subjek yang dilakukan pemberian terapi trombolisis intravena kebanyakan datang dalam waktu $>60$ menit dari onset kedatangan (waktu DTN $\leq 60$ menit), yaitu $63,9 \%$. Rerata skor NIHSS saat awal masuk $8,67 \pm 3,51$; menurun dalam 24 jam pertama menjadi $6,94 \pm 3,25$; hingga saat keluar dari RS 5,64 $\pm 5,50$. Adapun skor Indeks Barthel saat masuk RS adalah $57,91 \pm 19,27$ yang meningkat menjadi $73,33 \pm 26,25$ saat keluar dari RS.

\section{PEMBAHASAN}

Didapatkan 36 subjek yang mendapatkan rtPA sejak Januari 2017 hingga Mei 2018 (Tabel 1) dengan rerata usia 58 $\pm 8,63$ tahun. Risiko terkena stroke meningkat dengan bertambahnya usia, yaitu dua kali lipat setiap dekade setelah usia 45 tahun dan lebih dari $70 \%$ dari semua stroke terjadi di atas usia 65 tahun. $^{7}$

Proporsi laki-laki dan perempuan penelitian ini hampir sama, yaitu 53\% dan 47\%, sesuai dengan hasil di RS Cipto Mangunkusumo (52\%, dan 49\%). Angka kematian pada ras kulit putih pria dibanding wanita, 1:1. Pada kulit hitam, Latin dan Asian angka kematian lebih banyak pada pria. Bertolak belakang dengan yang lain pada ras India Amerika angka kematian lebih tinggi pada wanita. ${ }^{8}$ Angka kejadian di Amerika Serikat untuk stroke pada pria 1:6 dan 1:5 
Tabel 1. Karakteristik Subjek $(n=36)$

\begin{tabular}{|c|c|c|c|}
\hline Variabel & n $(\%)$ & $\operatorname{Rerata} \pm$ SD & $\begin{array}{c}\text { Median } \\
\text { (min-maks) }\end{array}$ \\
\hline \multicolumn{4}{|l|}{ Jenis Kelamin } \\
\hline - Laki-laki & $19(52,8)$ & & \\
\hline - Perempuan & $17(47,2)$ & & \\
\hline Usia (tahun) & & $58 \pm 8,63$ & $58(36-74)$ \\
\hline \multicolumn{4}{|l|}{ Merokok } \\
\hline - Ya & $11(30,6)$ & & \\
\hline - Tidak & $25(69,4)$ & & \\
\hline Onset (jam) & & $92,5 \pm 42,79$ & $90(15-180)$ \\
\hline Berat Badan (kg) & & $61,61 \pm 8,39$ & $60(50-80)$ \\
\hline GDS (mg/dL) & & $167,97 \pm 89,51$ & $142,5(60-419)$ \\
\hline Tekanan Sistolik (mmHg) & & $150,97 \pm 22,96$ & $150(110-190)$ \\
\hline Tekanan Diastolik (mmHg) & & $86,86 \pm 13,30$ & $87,5(63-112)$ \\
\hline \multicolumn{4}{|l|}{ Tipe Iskemik } \\
\hline - Lakuner & $29(80,6)$ & & \\
\hline - Teritorial & $7(19,4)$ & & \\
\hline \multicolumn{4}{|l|}{ Lokasi Iskemik } \\
\hline - Hemisfer dominan & $19(52,8)$ & & \\
\hline - Hemisfer nondominan & $17(47,2)$ & & \\
\hline Waktu Door to Needle & & $67,22 \pm 12,29$ & $65(51-120)$ \\
\hline$\bullet \leq 60$ menit & $13(36,1)$ & & \\
\hline - $>60$ menit & $23(63,9)$ & & \\
\hline \multicolumn{4}{|l|}{ NIHSS } \\
\hline - Saat masuk & & $8,67 \pm 3,51$ & $8(4-17)$ \\
\hline - 24 jam pertama & & $6,94 \pm 3,25$ & $6(3-14)$ \\
\hline - Saat keluar & & $5,64 \pm 5,50$ & $3,5(1-23)$ \\
\hline $\begin{array}{l}\text { Lama Perawatan (hari) } \\
\text { Indeks Barthel Masuk }\end{array}$ & & $8,28 \pm 3,97$ & $7,5(5-26)$ \\
\hline - $0-50$ & $12(33,3)$ & $57,91 \pm 19,27$ & $65(20-80)$ \\
\hline$\bullet 55-90$ & $24(66,7)$ & & \\
\hline \multicolumn{4}{|l|}{$\bullet 95-100$} \\
\hline \multicolumn{4}{|l|}{ Indeks Barthel Keluar } \\
\hline$\bullet 0-50$ & $5(13,9)$ & $73,33 \pm 26,25$ & $80(0-100)$ \\
\hline$\bullet 55-90$ & $21(58,3)$ & & \\
\hline - $95-100$ & $10(27,8)$ & & \\
\hline
\end{tabular}

SD: standar deviasi; GDS: gula darah sewaktu; NIHSS: National Institute of Health Stroke Scale.

untuk wanita, pria memiliki risiko yang lebih tinggi pada usia yang lebih muda dan wanita di usia yang lebih tua, setiap tahun 55.000 wanita mengalami stroke daripada pria. ${ }^{7}$ Prevalensi pasien terdiagnosis stroke pada usia 20-59 tahun, lebih banyak wanita dibanding pria. Namun pada usia $\geq 60$ tahun jumlah pasien pria lebih mendominasi. Berdasarkan ras, pasien pria berkulit hitam menduduki posisi terbanyak pada kelomposk usia 45-64 tahun. Sedangkan pada kelompok usia 65 tahun hingga $\geq 85$ tahun posisi terbanyak ditempati oleh pria berkulit putih. ${ }^{8}$

Penelitian ini didapatkan onset stroke iskemik akut adalah 15-180 menit dengan waktu DTN $\leq 60$ menit sebanyak 13 pasien $(36,1 \%)$ dan waktu DTN $>60$ menit sebanyak 23 pasien (63,9\%), penelitian di RSUPN Dr. Cipto Mangunkusumo menyimpulkan 
hanya $9,3 \%$ pasien yang menerima terapi trombolitik sebelum 3 jam onset stroke sementara 90,7\% pasien menerima terapi trombolitik antara 3-6 jam onset stroke. Sesuai pedoman AHA/ASA tahun 2018, bahwa waktu hingga diberikannya terapi rtPA adalah 3-4,5 jam. ${ }^{2,7}$

Sebagian besar subjek memiliki kadar GDS lebih normal $(167,97 \pm 89,51 \mathrm{mg} / \mathrm{dL})$. Gonzalez dkk menyatakan bahwa peningkatan kadar gula darah pada pasien stroke iskemik akut dapat disebabkan oleh beberapa hal. Adanya premorbid diabetes melitus sendiri merupakan faktor risiko terjadinya stroke iskemik melalui proses artheriosklerosis pada arteri-arteri intrakranial, terlebih pada pasien-pasien yang tidak terkontrol kadar gula darahnya. ${ }^{2}$

Selain itu, pada fase akut stroke iskemik, melalui proses inflamasi, tumor necrosis factor alpha (TNF- $\alpha$ ), interleukin-1 (IL-1), interleukin-6 (IL-6) mengaktivasi aksis hipotalamus-pituitarikelenjar adrenal (aksis HPA) yang mensekresikan kortisol, katekolamin, dan glukagon. Hal ini menyebabkan produksi berlebihan glukosa melalui proses glukogenolisis, glukoneogenesis, proteolisis, dan lipolisis. Aktivitas dari sitokin TNF- $\alpha$ telah dikaitkan dengan peningkatan resistensi insulin yang menambah beratnya hiperglikemia pada pasien stroke iskemik akut. $^{2}$

Peningkatan GDS pada pasien stroke akut memerlukan penatalaksanaan. Hal ini disebabkan karena penelitian mengenai peningkatan kadar glukosa dalam darah pada pasien stroke iskemik akut menunjukkan terdapat hubungan dengan luaran yang buruk, perluasan infark, dan eksaserbasi reperfusion injury. Penelitian pada model tikus menunjukkan bahwa tingkat reperfusi pada area penumbra tikus hiperglikemik lebih rendah (60\%) dibandingkan pada tikus normoglikemik (89\%), karena peningkatan superoksida yang menetralisir nitrat oksida yang berperan dalam vasodilatasi. ${ }^{9-10}$

Selain itu, superoksida yang meningkat juga ikut berperan dalam eksaserbasi reperfusion injury, mengingat mekanisme yang mendasari berkaitan dengan molekul spesies oksigen reaktif seperti superoksida dan peroksida. Atas dasar itulah, penanganan status hiperglikemik pada pasien stroke iskemik akut harus diperhatikan sebelum pemberian rtPA. ${ }^{11-13}$

Subjek penelitian ini memiliki tekanan darah yang tinggi saat masuk RS, yaitu rerata tekanan darah sistolik $150,97 \pm 22,97 \mathrm{mmHg}$ dan tekanan darah diastolik $86,86 \pm 13,30 \mathrm{mmHg}$. Peningkatan ini terjadi pada sebagian besar subjek, terutama dengan riwayat hipertensi sebelumnya. Dibandingkan dengan kejadian pada stroke hemoragik, pasien dengan stroke iskemik hanya menunjukkan peningkatan tekanan darah ringan sampai sedang. Diantara berbagai subtipe stroke iskemik, peningkatan tekanan darah pada stroke iskemik dengan infark lakuner tampak lebih tinggi dibandingkan dengan jenis lainnya. Hal ini menunjukkan bahwa hipertensi mempengaruhi pembuluh darah perforan kecil yang dapat menyebabkan infark lakuner, seperti yang dijumpai mayoritas stroke subjek penelitian ini berupa tipe lakunar $(80,6 \%){ }^{14}$

Dalam pedoman stroke, tekanan darah dipertahankan pada sistolik $220 \mathrm{mmHg}$ dan diastolik $120 \mathrm{mmHg}$. Hal tersebut disesuaikan berdasarkan autoregulasi tekanan bahwa aliran darah otak secara langsung tergantung pada tekanan darah. Khusus untuk pasien yang diindikasikan pemberian rtPA, tekanan darah harus dikontrol ke level $<185 / 110 \mathrm{mmHg}$ sebelum dilakukan tindakan dan harus dipertahankan pada level $<180 / 105 \mathrm{mmHg}$ untuk membatasi risiko perdarahan intraserebral. ${ }^{14-15}$

Rekomendasi AHA/ASA tahun 2018 adalah tekanan darah harus diturunkan $<185 / 110 \mathrm{mmHg}$ sebelum rtPA dan dipertahankan $<180 / 105 \mathrm{mmHg}$ hingga 24 jam setelahnya. Peningkatan mortalitas dan perdarahan intrakranial simtomatik terjadi pada pasien yang mendapatkan rtPA dengan tekanan darah yang tinggi. Namun demikian kurva hubungan luaran neurologis dan tekanan darah memiliki bentuk $\mathrm{U}$, yaitu bahwa pada tekanan darah yang terlalu rendah akan didapatkan pula peningkatan defisit neurologis. ${ }^{16-17}$

Sebagian besar subjek penelitian ini merupakan tipe iskemik lakuner $(80,6 \%)$ dan hanya $19,4 \%$ yang iskemik teritorial. Lokasi iskemik tersebut terutama pada hemisfer dominan (52,8\%). Penelitian 
sebelumnya didapatkan large artery atherosclerosis (LAA) adalah subtipe stroke yang paling umum pada $59,6 \%$, diikuti dengan penyakit pembuluh kecil (SVD) pada $26,7 \%$, etiologi yang tidak ditentukan pada 9,8\%, cardioembolism (CE) pada 2,1\%, dan etiologi lain yang ditentukan sebesar $0,9 \% .{ }^{18-19}$

Penelitian AHA/ASA pada tahun 2018, pada pasien dengan dominasi hemisfer kanan, didapatkan kejadian white matter hiperintense (WMH) berupa infark lakunar akut lebih banyak terletak pada bagian kanan dibandingkan kiri ( $81 \%$ berbanding $19 \%$; $\mathrm{p}<0,001)$. Disartria atapun afasia merupakan gejala klinis yang paling sering terjadi pada kejadian infark lakuner. Gangguan bahasa paling banyak terjadi pada stroke hemisfer kiri (hemisfer dominan). ${ }^{20-21}$

Di negara-negara Barat, penyebab stroke iskemik tersering adalah disebabkan karena emboli jantung, karena prevalensi stroke iskemik yang dikaitkan dengan penyakit arteri besar di negara-negara ini terus menurun, mungkin karena penanganan intensif terhadap faktor-faktor risiko aterosklerotik lebih baik. Sebaliknya, untuk populasi Asia penyebab stroke iskemik yang paling adalah sering penyakit pembuluh besar dan kecil. ${ }^{19}$

Stroke subkortikal kurang dari $20 \mathrm{~mm}$ dikaitkan dengan penyakit arteri besar dan bukan penyakit pembuluh darah kecil jika stenosis arteri, bahkan $<50 \%$, dalam arteri induk diidentifikasi. Stroke juga dikaitkan dengan penyakit arteri besar dengan aterosklerosis intra atau ekstrakranial ipsilateral dan ketika tidak ada penyebab lain diidentifikasi. ${ }^{24-25}$

Pada penelitian ini ditemukan perbaikan NIHSS secara bermakna pada hampir seluruh subjek, dinilai pada saat awal masuk RS, 24 jam pertama, serta saat keluar RS. Rerata skor NIHSS saat awal masuk $8,67 \pm 3,51$; menurun dalam 24 jam pertama menjadi $6,94 \pm 3,25$; hingga saat keluar dari RS 5,64 $\pm 5,50$. Rerata pengurangan skor $\geq 3,4(8,67-5,64)$, mendekati angka cut off point perbaikan klinis $4 .{ }^{26}$

NIHSS dapat digunakan untuk memprediksi kemungkinan pemulihan pascastroke, yaitu skor $\geq 16$ dapat berisiko kematian yang tinggi atau cacat parah, sedangkan skor $<16$ memperkirakan pemulihan yang baik. Perbaikan skor NIHSS $\geq 4$ pada hari ke- 7 menjadi indikator yang bermakna secara independen dengan luaran pasien stroke. ${ }^{29-30}$

Dalam uji coba National Institute of Neurological Disorders and Stroke (NINDS) yang membandingkan aktivator plasminogen jaringan intravena (tPA IV) dengan plasebo untuk pengobatan stroke iskemik akut, digunakan batas 4 poin untuk menentukan peningkatan dan perubahan fungsional yang signifikan secara klinis atau resolusi defisit neurologis lengkap. NIHSS mengukur defisit neurologis dan bukan hasil fungsional. ${ }^{31}$

Adapun skor Indeks Barthel saat masuk RS adalah 57,91 $\pm 19,27$ yang meningkat menjadi $73,33 \pm 26,25$ saat keluar dari RS. Indeks Barthel digunakan untuk melihat luaran perbaikan klinis stroke dalam kurun waktu 30 hari ada. Pada penelitian yang mengevaluasi manfaat trombolisis dengan dosis $0,6 \mathrm{mg} / \mathrm{kgBB}$ alteplase intravena untuk pasien stroke iskemik akut dalam waktu 6 jam dari serangan stroke, didapatkan hasil; setelah tiga bulan, 55,6\% pasien memiliki hasil fungsional yang baik dengan skor mRS 0-2. ${ }^{14}$

NIHSS dan Indeks Barthel merupakan skoring yang dapat menggambarkan hasil klinis pasien, hingga sering digunakan untuk menilai keberhasilan terapi trombolitik. Pada penelitian trombolisis di Indonesia sebelumnya, NIHSS dievaluasi pada 24 jam dan 7 hari setelah terapi trombolitik. Didapatkan hasil penurunan median NIHSS menurun pada 24 jam dan 7 hari pascatrombolisis. 33,3\% pasien mengalami pengurangan skor NIHSS $\geq 4$ pada 24 jam pascaterapi trombolitik. Pada hari ke 7 setelah trombolisis, 57,4\% pasien memiliki hasil klinis yang

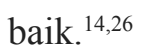

Pada penelitian tentang implementasi perawatan dalam stroke (SITS) trombolisis, skor 0-2 pada mRS hari 90 trombolisis menggambarkan independensi fungsional yang terjadi pada 55,4\% subjek. Hasil awal menunjukkan bahwa lama hasil disabilitas yang baik didefinisikan sebagai skor $m R S>3$, dan hasil fungsional yang buruk didefinisikan sebagai skor BI $<60$. Setelah tiga bulan, 55,6\% pasien memiliki hasil fungsional yang baik dengan skor mRS 0-2. Implementasi perawatan dalam stroke 
(SITS), pasien trombolisis, skor 0-2 pada mRS hari 90 pasca-trombolisis menggambarkan independensi fungsional yang terjadi pada $55,4 \%$ subjek. ${ }^{32-33}$

Terdapat 1 subjek (2,7\%) meninggal yang disebabkan komplikasi symptomatic intracerebral hemorrhage (sICH). Hal ini kemungkinan disebabkan karena kondisi hiperglikemia pada pasien saat di IGD dengan latar belakang diabetes melitus tidak terkontrol yang dapat menjadi salah satu faktor risiko terjadinya sICH. Penelitian sebelumnya mendapatkan hasil, terjadi komplikasi sICH pada 2-9\% dengan angka mortalitas mencapai 50\%. ${ }^{25-26}$

European Cooperative Acute Stroke Study (ECASS) III menyatakan sICH adalah perdarahan yang terlihat dari imaging dengan perburukan klinis neurologis dari pasien yang ditandai peningkatan NIHSS $\geq 4$ atau menyebabkan kematian. ${ }^{15,32}$ Penelitian di RSCM menyatakan bahwa pasien yang memiliki prediksi risiko sICH tinggi tidak menjadi alasan untuk menunda terapi trombolisis. Edukasi terhadap pasien dan keluarga terkait potensi komplikasi yang dapat terjadi mutlak dilakukan. Selain itu kepatuhan terhadap pedoman trombolisis yang telah terstandar harus dipenuhi. ${ }^{19,33}$

Mayoritas subjek datang dengan waktu DTN $>60$ menit. Keadaan ini dapat disebabkan oleh beberapa faktor yang memungkinkan mengapa terdapat keterlambatan dalam proses persiapan tindakan rtPA, yaitu kondisi pasien itu sendiri seperti gula darah sewaktu yang meningkat, tekanan darah yang tinggi saat akan dilakukan tindakan, serta kondisi dari luar seperti proses pengambilan sampel dan menunggu hasil laboratorium, prosedur pengiriman serta proses pemeriksaan CT scan kepala, sehingga menunda tindakan trombolisis intravena itu sendiri. ${ }^{10,20,29}$

Keterlambatan tersebut juga dapat akibat faktor pasien (tidak jelasnya onset serangan, riwayat penyakit dahulu, tidak terkontrolnya tekanan darah, naik turunnya kondisi defisit neurologis, dan tidak diketahuinya faktor koagulasi pasien) serta faktor pendukung (kurang tepat diagnosis saat di triase, tidak tersedianya tim code stroke, tidak tersedianya CT scan, keterlambatan hasil laboratorium, tidak tersedianya obat alteplase, dan pasien rujukan dari RS lain yang tidak mempunyai fasilitas pendukung rtPA. $25,33-34$

Pemberian alteplase di area radiologi diagnostik mengurangi waktu DTN sebesar 32\%; memindahkan pasien ke area radiologi diagnostik dari IGD mengurangi waktu DTN sebesar 30\%; mendaftarkan pasien sebagai pasien no name, sebelum identifikasi penuh oleh anggota keluarga atau informan, mengurangi waktu DTN sebesar $12 \%$; dan pemberitahuan serentak oleh grup telekomunikasi pasien dengan risiko tinggi stroke mengurangi waktu DTN sebesar $11 \% .^{32}$

Penyuntikan alteplase di area pemeriksaan CT scan dapat mempersingkat waktu DTN sebesar 32\%. Memindahkan pasien langsung ke CT dari triase IGD secara independen terkait dengan pengurangan 30\% dalam waktu DTN. Secara rutin mendaftarkan pasien dengan nomor ID unik yang tidak diketahui, alihalih mengidentifikasi pasien dan mencocokkannya dengan nomor ID yang diketahui, dikaitkan dengan waktu DTN 12\% lebih rendah. Pengurangan waktu DTN dengan menerapkan 4 strategi utama dan mengukur efek relatifnya: protokol prenotifikasi cSTAT stroke, mendaftarkan pasien sebagai pasien no name, memberikan alteplase di pemindai $\mathrm{CT}$ atau area pencitraan, dan memindahkan pasien ke CT dengan tempat tidur triase IGD. ${ }^{32-33}$

Salah satu penyebab utama penundaan waktu DTN adalah waktu bagi dokter untuk datang dan menilai, serta memberikan agen trombolitik kepada pasien. Perubahan dilaksanakan dengan memastikan bahwa trainee medis inti yang bertugas dialokasikan untuk merespons terhadap semua panggilan kemungkinan trombolisis. Hal ini menghasilkan pengurangan waktu rata-rata DTN, dari 74 menit pada November menjadi 43 menit pada Januari. Selain meningkatkan kondisi pasien, diperlukan pelatihan dan pengembangan keterampilan peserta pelatihan inti medis. ${ }^{34-35}$

Kunci utama manajemen definitif yang tepat adalah waktu transfer IGD ke door-to-imaging (DIT), dengan pedoman 25 menit atau kurang. Beberapa proses perawatan khusus stroke diketahui 
memperbaiki DIT, beberapa rekomendasi nasional untuk mengikuti proses berbasis bukti: prenotifikasi layanan medis darurat, protokol triase cepat, aktivasi tim panggilan tunggal stroke, toolkit, pengujian laboratorium cepat, pendekatan berbasis tim, dan umpan balik data yang cepat. ${ }^{34-35}$

Kepadatan pasien di IGD dapat berdampak buruk pada waktu. Hal ini belum dipertimbangkan dalam penelitian manajemen stroke akut, karena kebanyakan studi berfokus pada proses perawatan dan faktor spesifik pasien stroke. Kepadatan IGD dapat memengaruhi ketepatan waktu perawatan stroke, sehingga diperlukan manajemen tempat tidur rumah sakit yang terkoordinasi, unit rawat inap dan rawat inap sementara, protokol kapasitas maksimal rumah sakit, insentif keuangan, kenaikan kelas perawatan pasien di ruang rawat inap ketika IGD melebihi kapasitas, dan tim manajemen multidisiplin aliran pasien di rumah sakit. ${ }^{34-35}$

Keterbatasan penelitian ini adalah jumlah subjek yang masih minimal, sehingga dapat mengaburkan proporsi populasi pasien yang mendapatkan rtPA dengan waktu DTN $>60$ menit yang sebenarnya. Namun lebih dari separuh subjek penelitian memiliki waktu DTN $>60$ menit, sehingga terdapat kemungkinan hasil penelitian ini masih cukup menggambarkan capaian waktu DTN pasien stroke iskemik akut yang mendapatkan rtPA. Walaupun masih diperlukan peningkatan sistem pelayanan dengan target waktu DTN $\leq 60$ menit untuk mencapai luaran klinis yang maksimal.

\section{KESIMPULAN}

Didapatkan rerata awitan pasien stroke iskemik akut yang mendapatkan terapi rtPA berkisar 15-180 menit, sebagian besar pasien mengalami peningkatan tekanan darah dan tipe iskemik lakuner. Hal ini memberikan perbaikan skor NIHSS serta Indeks Barthel pada saat masuk dan saat keluar dari RS.

\section{DAFTAR PUSTAKA}

1. Gauberti M, Montagne A, Quenault A, Vivien D. Molecular magnetic resonance imaging of brain-immune interactions. Front Cell Neurosci. 2014;8:389.

2. Gonzalez-Moreno EI, Cámara-Lemarroy CR, González-González JG, Góngora-Rivera F. Glycemic variability and acute ischemic stroke: the missing link? Translational Stroke Res. 2014;5(6):638-46.

3. Powers WJ, Derdeyn CP, Biller J, Coffey CS, Hoh BL, Jauch EC, dkk. 2015 AHA/ASA focused update of the 2013 guidelines for the early management of patients with acute ischemic stroke regarding endovascular treatment. Stroke. 2015;46:3020-35.

4. Kernan WN, Ovbiagele B, Black HR, Bravata DM, Chimowitz MI, Ezekowitz MD, dkk. Guidelines for the prevention of stroke in patients with stroke and transient ischemic attack a guideline for healthcare professionals from the American Heart Association/ American Stroke Association. Stroke. 2014;45:2160236.

5. Winstein CJ, Stein J, Arena R, Bates B, Cherney LR, Cramer SC, dkk. Guidelines for adult stroke rehabilitation and recovery. Stroke. 2016;47(6):e98169.

6. Romano JG, Smith EE, Liang L. Outcomes in mild acute ischemic stroke treated with intravenous thrombolysis: A retrospective analysis of the get with the guidelines-stroke registry. JAMA Neurol. 2015;72(4):423-31.

7. Hayes MK. Influence of age and health behaviors on stroke risk: lessons from longitudinal studies. J Am Geriatr Soc. 2010:58(Supl 2):S325-8.

8. Mozaffarian D, Benjamin EJ, Go AS, Arnett DK, Blaha MJ, Cushman M, dkk. Heart disease and stroke statistics - 2015 update: a report from the American Heart Association. Circulation. 2015;131(4):e29-322.

9. Hafez S, Hoda MN, Guo X, Johnson MH, Fagan SC, Ergul A. Comparative analysis of different methods of ischemia/reperfusion in hyperglycemic stroke outcomes: interaction with tPA. Translational Stroke Res. 2015;6(3):171-80.

10. Hafez S, Coucha M, Bruno A, Fagan SC, Ergul A. Hyperglycemia, acute ischemic stroke and thrombolytic therapy. Transl Stroke Res. 2014;5(4):442-53.

11. Bruno A, Durkalski VL, Hall CE, Juneja R, Barsan WG, Janis S, dkk. The Stroke Hyperglycemia Insulin Network Effort (SHINE) trial protocol: a randomized, blinded, efficacy trial of standard vs. intensive hyperglycemia management in acute stroke. Intl J Stroke. 2014;9(2):246-51.

12. Chen R, Ovbiagele B, Feng W. Diabetes and stroke: epidemiology, pathophysiology, pharmaceuticals and outcomes. Am J Medical Sci. 2016;351(4):380-6.

13. Lind M, Polonsky W, Hirsch IB, Heise T, Bolinder J, Dahlqvist S. Continuous glucose monitoring vs conventional therapy for glycemic control in adults with type 1 diabetes treated with multiple daily 
insulin injections: the GOLD randomized clinical trial. JAMA Neurol. 2017;317(4):379-87.

14. Rasyid A, Harris S, Kurniawan M, Mesiano $T$, Hidayat R, Herqutanto, dkk. Efficacy of low-dose thrombolysis with intravenous alteplase within $6 \mathrm{~h}$ of acute ischemic stroke onset: evidence from single referral center in Indonesia. Intl J Pharm Pharma Sci. 2019;11(8):64-8.

15. Qureshi AI, Ezzeddine MA, Nasar A, Suri MF, Kirmani JF, Hussein HM, dkk. Prevalence of elevated blood pressure in 563704 adult patients with stroke presenting to the ED in the united states. Am J Emerg Med. 2007;25(1):32-8.

16. Vitt JR, Trillanes M, Hemphill JC. Management of blood pressure during and after recanalization therapy for acute ischemic stroke. Am J Emerg Med. 2007;25(1):32-8.

17. Powers WJ, Rabinstein AA, Ackerson T, Adeoye OM, Bambakidis NC, Becker K, dkk. Guidelines for the early management of patients with acute ischemic stroke: a guideline for healthcare professionals from the American Heart Association/American Stroke Association. Stroke. 2018;49(3):e46-99.

18. McManus M, Liebeskind DS. Blood pressure in acute ischemic stroke. J Clin Neurol. 2016;12(2):137-46.

19. Sharma VK, Tsivgoulis G, Teoh HL, Ong BK, Chan BP. Stroke risk factors and outcomes among various asian ethnic groups in Singapore. J Stroke Cerebrovasc Dis. 2012;21(4):299-304.

20. Urban PP, Rolke R, Wicht S, Keilmann A, Stoeter $\mathrm{P}$, Hopf HC, dkk. Left-hemispheric dominance for articulation: a prospective study on acute ischaemic dysarthria at different localizations. J Oxford. 2015;129(Pt 3):767-77.

21. Hedna VS, Bodhit AN, Ansari S, Falchook AD, Stead L, Heilman KM, dkk. Hemispheric differences in ischemic stroke: is left-hemisphere stroke more common? J Clin Neurol. 2014;9(2):97-102.

22. Ryu WS, Schellingerhout D, Ahn HS, Park SH, Hong KS, Jeong SW, dkk. Hemispheric asymmetry of white matter hyperintensity in association with lacunar infarction. J Am Heart Assoc. 2018;7(22):e010653.

23. Natanzi N, Ashourpour S, Goel P, Nance PW. Right thalamic lacunar infarction presenting with anomic aphasia. IJDHD. 2015;14(2):193-6.

24. Wasay M, Khatri IA, Kaul S. Stroke in South Asian countries. Nat Rev Neurol. 2014;10(3): 135-43.

25. Ahn SH, Lee J, Kim YJ, Kwon SU, Lee D, Jung $\mathrm{SC}$, dkk. Isolated MCA disease in patients without significant atherosclerotic risk factors. Stroke. 2015;46(3):697-703.

26. Advani R, Naess H, Kurz MW. Evaluation of the implementation of a rapid responsse treatment protocol for patients with acute onset stroke: can we increase the number of patients treated and shorten the time needed? Cerebrovasc Dis Extra. 2014;4(2):115-21.

27. Broderick JP, Palesch YY, Demchuk AM, Yeatts SD, Khatri P, Hill MD, dkk. Endovascular therapy after intravenous t-PA versus t-PA alone for stroke. Engl J Med. 2013;368(10):893-903.

28. Young FB, Weir CJ, Lees KR. Comparison of the National Institutes of Health Stroke Scale with disability outcome measures in acute stroke trials. Stroke. 2005;36(10):2187-92.

29. Adams HP, Bendixen BH, Kappelle LJ, Biller J, Love BB, Gordon DL, dkk. Classification of subtype of acute ischemic stroke. Definitions for use in a multicenter clinical trial. TOAST. Trial of Org 10172 in Acute Stroke Treatment. Stroke. 1993;24(1):35-41.

30. Kasner SE, Chalela JA, Luciano JM, Cucchiara BL, Raps EC, McGarvey ML, dkk. Reliability and validity of estimating the NIHS stroke scale score from medical records. Stroke. 1999;30(8):1534-7.

31. The National Institute of Neurological Disorders and Stroke rt-PA Stroke Study Group. Tissue plasminogen activator for acute ischemic stroke. N Engl J Med. 1995;333(24):1581-8.

32. Rasyid A, Salim H, Eny N, Joedo P. Pentoxifylline in acute ischemic stroke patients with blood hyperviscosit. Intl $\mathrm{J}$ Applied Pharmaceutics. 2018;10(1):307-10.

33. Bowry R, Navalkele DD, Gonzales NR. Blood pressure management in stroke: five new things. Neurol: Clin Practice. 2014;4(5):419-26.

34. Yaghi S, Eisenberger A, Willey JZ. Symptomatic intracerebral hemorrhage in acute ischemic stroke after thrombolysis with intravenous recombinant tissue plasminogen activator. JAMA Neurol. 2014;71(9):1181-5.

35. Rasyid A, Harris S, Kurniawan M, Hidayat R, Mesiano T. Prediktor symptomatic intracerebral hemorrhage pascatrombolisis intravena pada stroke iskemik akut. Neurona. 2018;35(3):194-9.

36. Jeon SB, Koh YS, Choi HA, Leec KW. Critical care for patients with massive ischemic stroke. J Stroke. 2014;16(3):146-60.

37. Mcdermott M, Jacobs T, Morgenstern L. Dalam: Aminoff MJ, Boller F, Swaab DF, editor. Edisi Ke3. Critical care in acute ischemic stroke. Handbook of clinical neurology. Volume 140. Amsterdam: Elsevier; 2017. h. 153-76.

38. Sauser K, Levine DA, Nickles AV, Reeves MJ. Hospital variation in thrombolysis times among patients with acute ischemic stroke: the contributions of door-to-imaging time and imaging-to-needle time. JAMA Neurol. 2014;71(9):1155-61. 
39. Reznek MA, Murray E, Youngren MN, Durham NT, Michael SS. Door-to-imaging time for acute stroke patients is adversely affected by emergency department crowding. 2017;48(1):49-54.

40. Kuhrij LS, Marang-Van-De-Mheen PJ, Van-DenBerg-Vos RM, De-Leeuw FE, Nederkoorn PJ, Dutch
Acute Stroke Audit Consortium. Determinants of extended door-to-needle time in acute ischemic stroke and its influence on in-hospital mortality: results of a nationwide Dutch clinical audit. BMC Neurol. 2019;19(1):265. 